Pobrane z czasopisma Annales H - Oeconomia http://oeconomia.annales.umcs.pl Data: 26/04/2023 02:59:28

DOI:10.17951/h.2016.50.4.457

\begin{tabular}{lcl}
\hline \multicolumn{3}{c}{ A N N A L E S } \\
UNIVERSITATIS MARIAE CURIE-SKŁODOWSKA \\
LUBLIN - POLONIA \\
VOL. L, 4 & SECTIOH \\
\hline
\end{tabular}

Uniwersytet Łódzki. Wydział Ekonomiczno-Socjologiczny

\title{
WOJCIECH STARZYŃSKI
}

wojciech.starzynski@uni.lodz.pl

\section{Leasing i kredyt $w$ systemie zamówień publicznych $w$ Polsce na tle innych krajów UE}

Leasing and Bank Credit in the System of Public Procurement in Poland in Comparison with Other European Countries

Słowa kluczowe: leasing; kredyt; prawo zamówień publicznych

Keywords: leasing; bank credit; public procurement law

Kod JEL: G32

\section{Wstęp}

Instytucje publiczne, zwłaszcza w okresie spowolnienia gospodarczego, są zmuszane do szukania alternatywnych źródeł finansowania swoich inwestycji. Finansowanie inwestycji za pomocą leasingu jest najstarszą alternatywą wobec kredytu. Jako forma wspierania inwestycji jest bezpieczniejszym, bardziej elastycznym, łatwiejszym do pozyskania i często mniej kosztownym sposobem niż kredytowanie. O ile literatura przedmiotu w zakresie analizy tych dwóch sposobów finansowania inwestycji w przedsiębiorstwach jest dość bogata, o tyle brak jest prac na temat mechanizmów podejmowania decyzji przez podmioty sektora publicznego.

Celem niniejszego artykułu jest analiza zamówień publicznych na kredyt i leasing jako źródeł finansowania inwestycji przez sektor publiczny w Polsce w latach 2010-2014. W pracy wykorzystano dane pochodzące z europejskiej bazy danych 
$\mathrm{TED}^{1}$, która zawiera informacje o zamówieniach publicznych o wartości równej lub przekraczającej tzw. progi unijne, oraz dane z Biuletynu Zamówień Publicznych (BZP), w którym publikuje się ogłoszenia dotyczące zamówień publicznych o wartości poniżej tych progów.

Według danych GUS z 2015 r. w strukturze podmiotowej klientów (leasingobiorców) rynku usług leasingowych w Polsce dominowały przedsiębiorstwa $(89,9 \%)$, które wzięły w leasing środki na kwotę $36159 \mathrm{mln}$ zł. Osoby fizyczne stanowiły 9,6\% klientów i wzięły w leasing środki na kwotę $1613 \mathrm{mln}$ zł, natomiast leasingobiorcy z administracji publicznej stanowili 0,5\% klientów i wyleasingowali środki na kwotę $54 \mathrm{mln}$ zł [GUS, 2016].

\section{Kredyt i leasing jako przedmiot zamówień publicznych}

Specyfiką leasingu w zamówieniach publicznych jest połączenie zamówień należących do dwóch różnych rodzajów. Zamawiający zamawia zarówno dostawę, jak i usługę finansową. Leasing jest usługą finansową i w związku $\mathrm{z}$ tym jest klasyfikowany jako usługa. Drugim rodzajem jest dostawa, która będzie finansowana w wyniku zawarcia umowy leasingu. Powyższe determinuje konieczność podawania co najmniej dwóch kodów CPV przy zamawianiu dostaw realizowanych na podstawie leasingu ${ }^{2}$. Zgodnie $\mathrm{z}$ zasadami systematyki zamówień publicznych zamówienia takie są klasyfikowane jako dostawy. Decyduje o tym zaimplementowana w prawie krajowym definicja dostaw.

Każdorazowo zamawiający, który zamierza finansować dostawę, musi opisać przedmiot zamówienia w sposób umożliwiający przygotowanie oferty łączącej dostawę z usługą finansową. W systemie funkcjonowania zamówień publicznych ukształtowała się praktyka, w której wiodącą rolę przy realizacji dostawy pełni instytucja finansowa. W odpowiedzi na zamówienie usługodawca wyszukuje dostawcę, z którym podpisuje umowę na dostawę, jednocześnie oferując tę dostawę zamawiającemu na zasadach określonych w umowie leasingowej. Pomimo faktu, że zamawiający traci bezpośredni wpływ na wybór dostawcy, konkurencyjność jest zachowana. Podmiot finansujący dostawę musi w ofercie składanej wykonawcy skalkulować koszt zakupu i usługi finansowej. Im niższy koszt zakupu, tym większe możliwości wygenerowania zysku na usłudze finansowej, oczywiście w granicach, na które pozwala rynkowa konkurencja. W efekcie końcowym udział w realizacji takiej dostawy mają dwa podmioty: dostawca dobra stanowiącego przedmiot za-

1 TED (Tenders Electronic Daily) - internetowa wersja Suplementu do Dziennika Urzędowego Unii Europejskiej, będąca częścią oficjalnego portalu Unii Europejskiej.

2 Wspólny Słownik Zamówień Publicznych (CPV) został utworzony dla potrzeb wspólnego systemu zamówień publicznych. W Polsce od 2008 r. funkcjonuje system CPV 2008, który obejmuje kody składające się maksymalnie z 9 cyfr, powiązane ze słownymi sformułowaniami stanowiącymi opis dostaw, robót budowlanych lub usług. 
mówienia oraz instytucja finansowa, która umożliwia zakup w drodze leasingu. W tym przypadku dostawca nie jest zainteresowany sprzedażą, której okres spłaty jest rozłożony w czasie.

W sytuacji dużych jednostkowych dostaw (często na rynku sektorowym np. sprzętu górniczego, kolejowego) zamówienie może być realizowane wyłącznie przez jednego wykonawcę, który pełni jednocześnie dwie role. Jest dostawcą, najczęściej producentem przedmiotu zamówienia, oraz ma odpowiednią płynność finansową do rozłożenia zobowiązania finansowego w czasie. Podmiot taki, omijając pośrednika w postaci instytucji finansowej, może zaoferować korzystniejsze warunki finansowe zamawiającemu $z$ uwagi na możliwość wprowadzenia upustu od zagregowanego zysku, z zamówienia na dostawę i z usługi finansowej.

Ważnym elementem dostaw realizowanych $\mathrm{w}$ drodze umowy leasingu jest ograniczone ryzyko instytucji finansującej zamówienie, która jest właścicielem przedmiotu dostawy. Zbliżoną funkcję, z punktu widzenia finansowania instytucji zamawiającej, pełni kredyt, który w systemie zamówień publicznych znacząco różni się od leasingu. Kredyt jest wyłącznie usługą finansową, która może być przeznaczona na dowolny cel wskazany przez zamawiającego. Może to być np. spłata bieżącego zadłużenia instytucji publicznej lub finansowanie nowego przedsięwzięcia. Z uwagi na zachowanie dyscypliny budżetowej usługa kredytowa może być wykorzystywana w szczególnych sytuacjach i przez podmioty publiczne, które w części lub całości funkcjonują na wolnokonkurencyjnym rynku (np. placówki służby zdrowia). Różnica między kredytem a dostawą $\mathrm{w}$ formie leasingu pojawia się także $\mathrm{w}$ podwyższonym ryzyku instytucji kredytującej. Brak zabezpieczenia materialnego powoduje, że roszczenia wobec zamawiającego mogą być podejmowane na ogólnych zasadach.

Usługa leasingu na rynku zamówień publicznych jest traktowana jako innowacyjna forma finansowania inwestycji rzeczowych w relacji do kredytu bankowego. Szczególną popularność osiągnął leasing w czasie panującego kryzysu finansowego, w którym przedsiębiorstwa i instytucje administracji publicznej poszukiwały źródeł kapitału zapewniających mniejsze koszty niż te związane z uzyskaniem kredytu bankowego [Dąbkowski, 2013, s. 39-52]. Łatwiejsze procedury zawarcia umowy leasingowej i atrakcyjniejsze cenowo wobec narastających wymogów banków komercyjnych będą zachęcać do korzystania $\mathrm{z}$ tego rodzaju finansowania inwestycji przez podmioty zamawiające.

\section{Zamówienia publiczne na kredyt i leasing w Polsce w świetle danych BZP}

W przypadku analizy zamówień publicznych przez krajowe podmioty zamawiające można skorzystać z dwóch baz danych: BZP i TED. Dostęp do relacyjnej bazy zbudowanej z ogłoszeń przesyłanych do BZP nie istnieje. Urząd Zamówień Publicznych (UZP) taką bazę zapewne posiada, gdyż jej brak uniemożliwiałby tej instytucji podawanie w rocznych sprawozdaniach syntetycznych danych dotyczących rynku 
zamówień publicznych. Istnieje natomiast możliwość zbudowania relacyjnej bazy danych przez zainteresowanych, ponieważ na portalu UZP dostępne są informacje umożliwiające taką czynność.

Na serwerze FTP, zainstalowanym na portalu centralnym [ftp://ftp.uzp.gov.pl/bzp/ $\mathrm{xml}$ ] UZP, udostępniono zarchiwizowane dane przesyłane do BZP przez zamawiających. Dla ułatwienia, osobom chcącym zbudować bazę danych, udostępniono informacje w różnych systemach plików: „XML”, „CSV” oraz „HTML”. Uniwersalność plików „XML” i brak ograniczeń w pobieraniu informacji ułatwiają pracę z danymi.

Inną bardzo czasochłonną metodą uzyskiwania danych dotyczących zamówień „biuletynowych” jest bezpośrednie wyszukiwanie ogłoszenia bądź zbioru ogłoszeń na portalu Urzędu Zamówień Publicznych [http://bzp1.portal.uzp.gov.pl/index. php?ogloszenie= $=$ browser].

Niezależnie od możliwości, jakie daje budowa własnej bazy danych, można skorzystać z informacji, które corocznie w okresie maj - czerwiec publikuje UZP w rocznych sprawozdaniach z funkcjonowania systemu. Są to niestety dane bardzo syntetyczne, w praktyce uniemożliwiające prowadzenie bardziej szczegółowych analiz z wykorzystaniem kodów Wspólnego Słownika Zamówień CPV. Analiza na poziomie, jakim są działy, nie jest możliwa. Rys. 1 prezentuje liczbę udzielonych kredytów i dostaw finansowanych w formie leasingu w Polsce w latach 2010-2014.

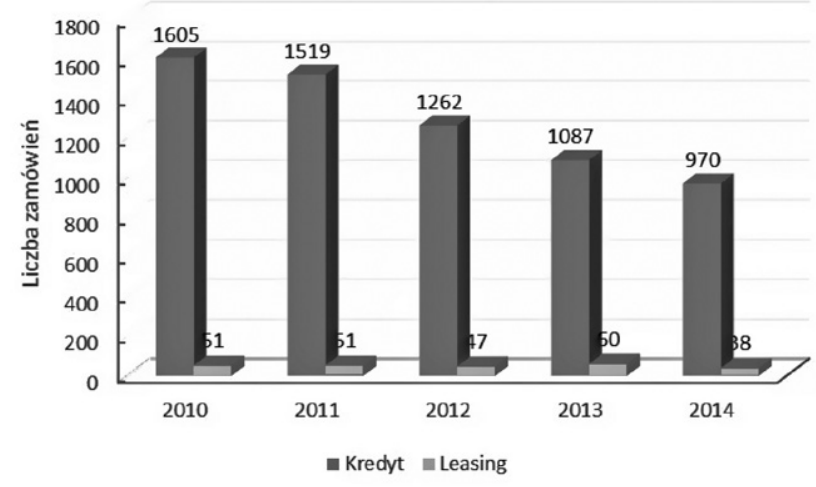

Rys. 1. Liczba udzielonych zamówień o wartościach niższych od progów unijnych na usługę kredytową oraz dostawy finansowane w formie leasingu w Polsce w latach 2010-2014

Źródło: opracowanie własne na podstawie danych z BZP.

W obszarze zamówień, których wartość nie przekracza progów unijnych, aktywność krajowych podmiotów publicznych chcących finansować dostawy przez kredyt jest wielokrotnie wyższa niż w przypadku leasingu, chociaż w tym pierwszym przypadku obserwowane wielkości mają tendencję wyraźnie spadkową.

$\mathrm{Z}$ uwagi na ograniczenia europejskiego systemu zamówień publicznych w zakresie sprawozdawczości brak jest możliwości przyzwolenia porównań aktywności 
zamawiających (zagranicznych) w zakresie zamówień, których wartość jest niższa od progów unijnych. Na podstawie dostępnych danych z europejskiego systemu zamówień można domniemywać, że w tej grupie zamówień Polska jest europejskim liderem w zakresie omawianych usług.

Analiza wykonawców zamówień publicznych na usługi leasingu w świetle danych BZP prowadzi do wniosku, że w latach 2010-2014 leasingu przez zamówienia publiczne najczęściej udzielało BRE Leasing. Przedsiębiorstwo to finansowało co piąte zamówienie publiczne. 15-procentowym udziałem charakteryzuje się Europejski Fundusz Leasingowy, przy czym był on wykonawcą zamówień publicznych na usługi leasingu tylko tych ogłaszanych w BZP (o wartości niższej od tzw. progów unijnych). Z kolei PKO Leasing z 11-procentowym udziałem znalazło się na trzecim miejscu, finansując zamówienia publiczne ogłaszane zarówno w Biuletynie Zamówień Publicznych, jak i w Dzienniku Urzędowym UE (TED).

\section{Analiza porównawcza skali zamówień publicznych na kredyt i leasing w krajach czlonkowskich UE}

W celu zebrania danych wykorzystano bazę TED, włączając w zakres przeszukiwania wszystkie kraje członkowskie UE według ustawień z tab. 1.

Tab. 1. Parametry przeszukiwania bazy danych TED dla $2014 \mathrm{r}$.

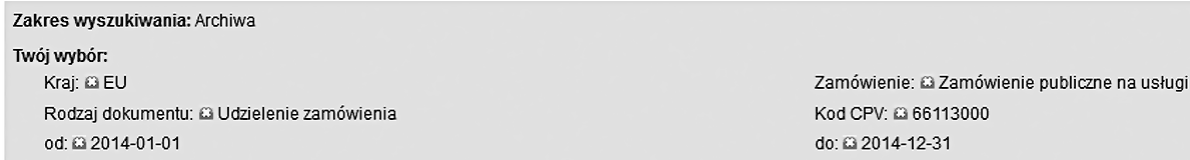

Źródło: opracowanie własne na podstawie publikacji w TED.

Przeszukiwanie powtórzono jeszcze trzykrotnie, zbierając dane za lata 2010 2013, a uzyskane wyniki przedstawiono graficznie na rys. 2. Podjęta próba zebrania danych umożliwiających zorientowanie się w skali zamówień na kredyty dla instytucji publicznych w krajach Unii Europejskiej potwierdziła, że krajowe podmioty są liderem europejskim w zakresie jej zamawiania. Rokrocznie ponad 50\% wszystkich udzielonych kredytów, zawartych przez podmioty publiczne, których wartość przekracza progi wyznaczone przez dyrektywy, należy do polskich zamawiających publicznych. W analogicznym zakresie przeszukano europejską bazę zamówien, wyszukując dane dotyczące europejskiego rynku dostaw realizowanych na podstawie umowy leasingu. Zebrane dane prezentuje rys. 3.

$\mathrm{Z}$ prezentowanych danych na rys. 2 i 3 jednoznacznie wynika, że polskie podmioty sektora publicznego składają najwięcej zamówień na usługi finansowe. Trudno jest także nie zauważyć, że w badanym okresie żaden grecki podmiot publiczny nie 
Pobrane z czasopisma Annales $\mathrm{H}$ - Oeconomia http://oeconomia.annales.umcs.pl Data: 26/04/2023 02:59:28

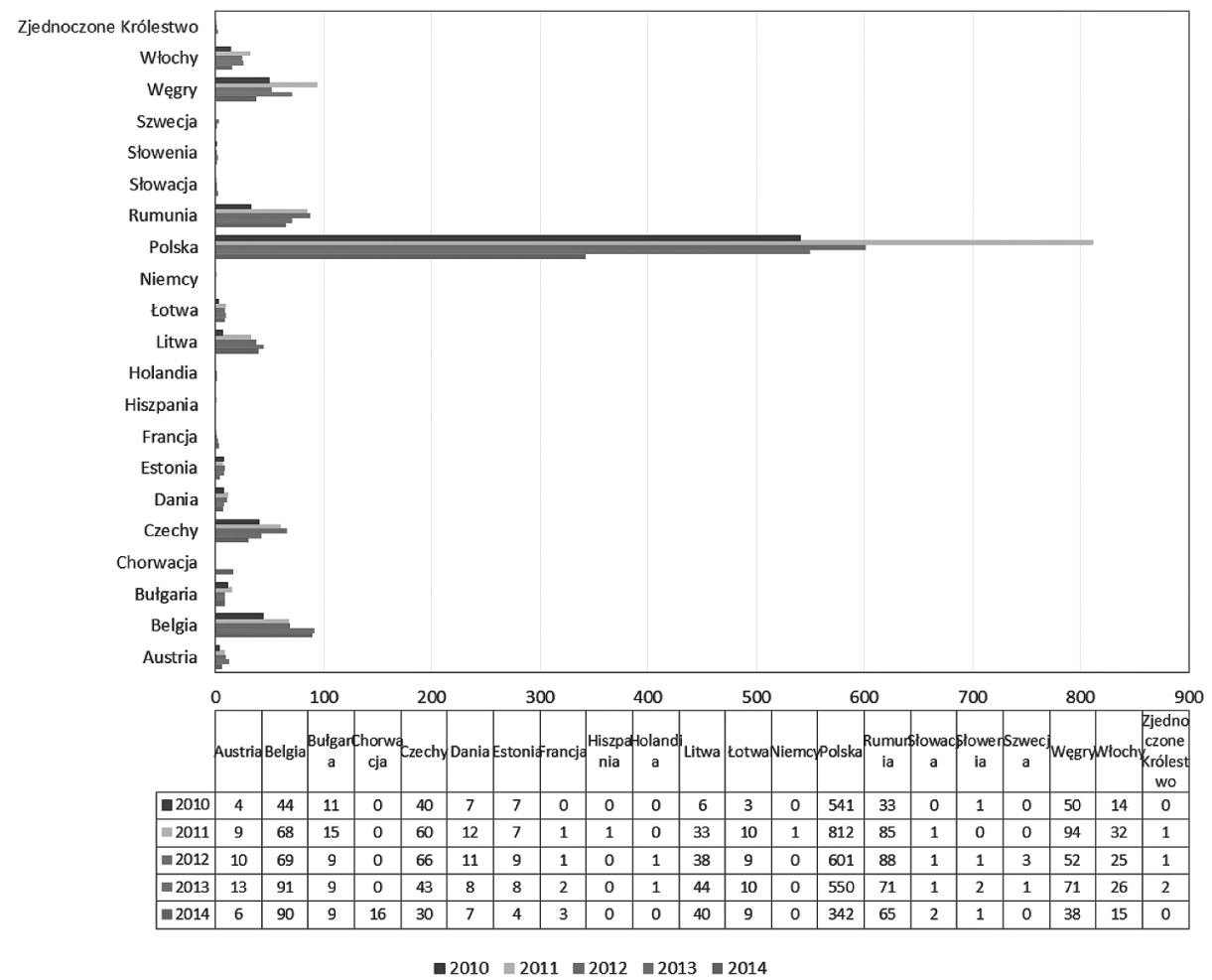

Rys. 2. Liczba udzielonych zamówień publicznych na kredyty przez kraje UE w latach 2010-2014

Źródło: opracowanie własne na podstawie danych z bazy TED.

starał się o kredyt czy leasing. Struktura zamówień publicznych w Polsce w podziale na rodzaj leasingu różni się w zależności od tego, czy wartość zamówienia przekracza progi unijne czy też jest od nich niższa. W zamówieniach publikowanych w BZP najczęściej występuje leasing operacyjny. W 2013 r. stanowił on 84\%, charakteryzując się od $2010 \mathrm{r}$. tendencją rosnącą. Z kolei w zamówieniach publicznych w TED najczęstszą formą leasingu jest leasing finansowy, stanowiący np. w $2013 \mathrm{r}$. $61 \%$ ogółu zamówień na dostawy leasingu. Pewne różnice w strukturze leasingu ze względu na przedmiot zamówienia można odnotować w dwóch grupach zamówień: poniżej i powyżej progów unijnych.

Jeśli chodzi o dane publikowane w BZP, to największą część analizowanego rynku stanowił sprzęt transportowy (w 2013 r. - 65\%), urządzenia medyczne (10\%), maszyny rolnicze (8\%), maszyny przemysłowe (6\%) i sprzęt budowlany (5\%). Wśród zamówień o wartości powyżej progów unijnych również dominował sprzęt transportowy, którego udział w 2013 r. wyniósł 43\%. Na kolejnym miejscu znalazły się maszyny górnicze i sprzęt budowlany (22\%), maszyny przemysłowe (11\%), sprzęt radiowy, telewizyjny i komunikacyjny (9\%) oraz urządzenia medyczne i farmaceutyki (7\%). 
Pobrane z czasopisma Annales H - Oeconomia http://oeconomia.annales.umcs.pl

Data: 26/04/2023 02:59:28

LEASING I KREDYT W SYSTEMIE ZAMÓWIEŃ PUBLICZNYCH W POLSCE NA TLE INNYCH KRAJÓW... 463

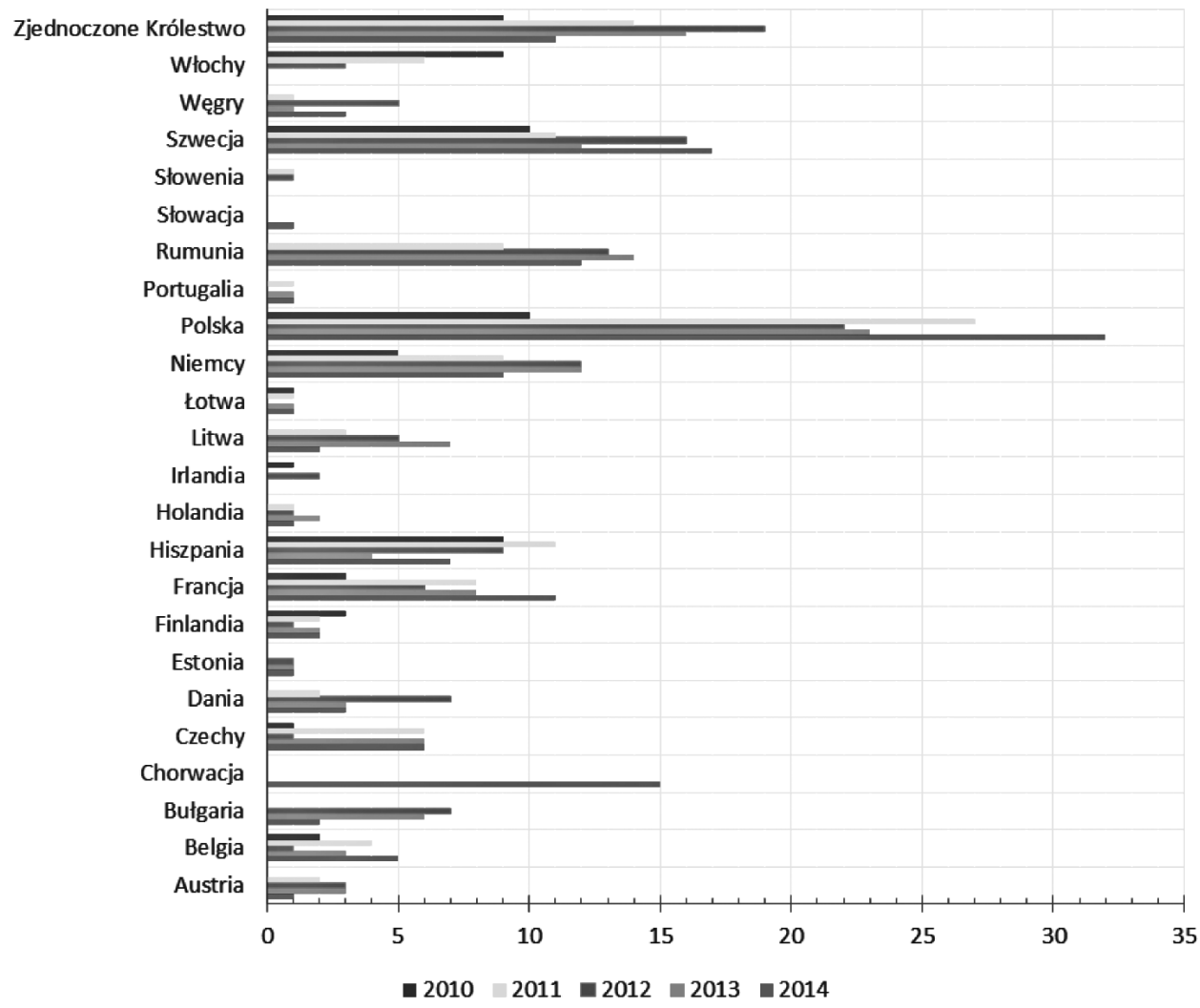

Rys. 3. Liczba zamówień na dostawy finansowane w drodze leasingu udzielone przez kraje UE w latach 2010-2014

Źródło: opracowanie własne na podstawie danych z bazy TED.

Konkurencyjność zamówień publicznych na dostawy w formie leasingu zależy głównie od wartości zamówienia. W 2013 r. na jedno postępowanie ogłoszone w Dzienniku Urzędowym UE przypadało 2,12 oferty, podczas gdy w ogłoszeniach publikowanych w BZP ten miernik wyniósł zaledwie 1,41. Generalnie rynek zamówień publicznych na dostawy charakteryzuje się relatywnie dużą konkurencyjnością, natomiast $\mathrm{w}$ segmencie zamówień publicznych na usługi leasingu konkurencyjność jest znacznie niższa. Eksperci tłumaczą to zjawisko w ten sposób, że jest to wynikiem złożoności natury samego przedmiotu zamówienia i nie zawsze odpowiadających danemu przedmiotowi warunków jego finansowania. Ponadto, jak się wydaje, towarzystwa leasingowe są znacznie mniej zainteresowane uczestnictwem w postępowaniach, w których ze względu na skomplikowany na ogół przedmiot zamówienia warunkiem ich udziału w procedurze przetargowej jest przejęcie przez nie odpowiedzialności za wybór dostawy przedmiotu leasingu [Starzyński, 2014, s. 39]. 
Najczęściej w rynku zamówień publicznych w zakresie dostaw w formie leasingu uczestniczą: Europejski Fundusz Leasingowy, Raiffeisen Leasing Polska, Leasing czy BZWBK Leasing.

\section{Podsumowanie}

Wartość polskiego rynku zamówień publicznych w latach 2010-2013 (2014) wahała się od 132,7 do 167 mld zł [Sprawozdania Prezesa UZP o funkcjonowaniu systemu zamówień publicznych w latach 2010-2014]. Wartość zrealizowanych dostaw w formie leasingu to zaledwie 0,5 mld zł w 2013 r., co stanowi $0,3 \%$ rynku zamówień publicznych i 1,7\% rynku ogółu usług leasingowych.

Podjęta $\mathrm{w}$ artykule próba porównania dwóch form finansowania sektora publicznego prowadzi do wniosku, że w przypadku zamówień o wartości poniżej progów unijnych zdecydowanie większą rolę odgrywa kredyt, gdyż ta forma finansowania inwestycji jest wielokrotnie częściej stosowana przez polskich zamawiających. Leasing jest wykorzystywany głównie w przypadku pojazdów specjalistycznych, osobowych, sprzętu medycznego oraz serwerów. Należy podkreślić, że o ile liczba transakcji leasingowych jest $\mathrm{w}$ skali roku na dość zbliżonym poziomie (od 38 do 60 ), o tyle liczba zrealizowanych kredytów charakteryzuje się w badanym okresie wyraźnie tendencją malejącą (od 1605 w 2010 r. do 970 w 2014 r.).

Jeśli chodzi o analogiczne zamówienia publiczne o wartości równej lub wyższej od progów unijnych, to liczba kredytów (charakteryzująca się również tendencją spadkową) jest tutaj niższa (od 812 w 2014 r. do 342 w 2014 r.), natomiast liczba usług leasingowych rośnie. Jak się wydaje, leasing w ostatnich kilku latach jest pewną alternatywą dla kredytu w zakresie finansowania sektora publicznego.

Porównania międzynarodowe dowodzą, że krajowe podmioty zamawiające są liderem europejskim w zakresie zamówień publicznych na kredyty, ponieważ ponad $50 \%$ wszystkich udzielonych w skali roku kredytów sektorowi publicznemu w UE należy do polskich zamawiających.

\section{Bibliografia}

BZP, http://bzp1.portal.uzp.gov.pl [data dostępu: 16.01.2014].

Dąbkowski A., Innowacje w leasingu - leasing tenencyjny, zwrotny, norweski, lombardowy, Akademia Finansów i Biznesu Vistula, Warszawa 2013.

$\mathrm{ftp}: / / \mathrm{ftp} . u z p . g o v . p l / \mathrm{bzp} / \mathrm{xml}$ [data dostępu: 16.01.2014].

GUS, Działalność przedsiębiorstw leasingowych w 2015 r. Warszawa 2016.

http://bzp1.portal.uzp.gov.pl/index.php?ogloszenie=browser [data dostępu: 16.01.2014].

Sprawozdania Prezesa UZP o funkcjonowaniu systemu zamówień publicznych w latach 2010-2014.

Starzyński W., Leasing $w$ systemie zamówień publicznych $w$ Polsce - uwarunkowania i ocena, „Annales

UMCS. Sectio H” 2014, Vol. XLVIII, nr 4, DOI: http://dx.doi.org/10.17951/h.2014.48.4.235.

TED, http://ted.europa.eu/TED/search/search.do [data dostępu: 16.01.2014]. 


\section{Leasing and Bank Credit in the System of Public Procurement in Poland in Comparison with Other European Countries}

Concluding leasing and bank credit contracts public sector entities are subject to, as all other expenditures on services and goods, the rigors of public procurement law. The aim of the paper is to compare how often these two sources of public financing are used in Poland and other European countries. As for public procurement of value less than so-called European thresholds, Poland is characterized by very high amount of bank credits in comparison with leasing services. In case of public procurement with higher values (more than the EU thresholds), the situation in the period 2010-2014 is the same, however, tendency of amount of bank credits is decreasing, while the number of leasing contracts slowly increases. The Polish public entities are leaders in the EU especially in the area of public contracts for bank credits. It could be explained by their preferences in the field of financial means by such procedures which do not require additional complicated description of public procurement subject. Bank credits fulfill such a condition.

\section{Leasing i kredyt w systemie zamówień publicznych w Polsce na tle innych krajów UE}

Zawieranie umów leasingowych i kredytowych przez podmioty sektora publicznego podlega (podobnie jak inne wydatki na dobra i usługi) wymogom prawa zamówień publicznych. Podjęta w artykule próba porównania tych dwóch form finansowania sektora publicznego w latach 2010-2014 prowadzi do wniosku, że w przypadku zamówień o wartości poniżej progów unijnych zdecydowanie dominuje kredyt. Dla zamówień publicznych o wartości równej co najmniej progom unijnym ta przewaga jest nadal duża, chociaż malejącej tendencji umów kredytowych towarzyszy rosnący trend liczby umów leasingowych. Porównania międzynarodowe wskazują, że krajowe podmioty zamawiające są liderem europejskim w zakresie zamówień publicznych na usługi kredytu. Wysoka liczba kredytów, przy relatywnie niskiej liczbie zawieranych kontraktów na dostawy leasingu, może świadczyć o preferencjach potencjalnych zamawiających w zakresie pozyskiwania środków pieniężnych przez takie procedury, które nie wymagają skomplikowanego opisu przedmiotu zamówienia, co spełniają kredyty, podczas gdy specyfiką leasingu jest połączenie dwóch rodzajów zamówień: dostaw i usług finansowych. 